Running title: Suillus luteus inhibits proliferation of a colon cancer cell line

\title{
Suillus luteus methanolic extract inhibits cell growth and proliferation of a colon cancer cell line
}

Tiago dos Santos ${ }^{\mathrm{a}}$, Catarina Tavares ${ }^{\mathrm{a}}$, Diana Sousa, ${ }^{\mathrm{a}, \mathrm{b}}$, Josiana A. Vaz ${ }^{\mathrm{a}, \mathrm{c}}$, Ricardo C. Calhelha $^{\mathrm{c}, \mathrm{d}}$, Anabela Martins ${ }^{\mathrm{c}}$, Gabriela M. Almeida ${ }^{\mathrm{a}}$, Isabel C.F.R. Ferreira ${ }^{\mathrm{c}^{*}}$, M. Helena Vasconcelos ${ }^{\mathrm{a}, \mathrm{e}^{*}}$

${ }^{a}$ Cancer Drug Resistance Group, IPATIMUP - Institute of Molecular Pathology and Immunology of the University of Porto, Porto, Portugal

${ }^{b}$ CEQUIMED-UP-Centre of Medicinal Chemistry of the University of Porto, Porto, Portugal

${ }^{c}$ Mountain Research Centre (CIMO), Polytechnic Institute of Bragança, Campus de Santa Apolónia, Apartado 1172, 5301-855 Bragança, Portugal

${ }^{d}$ Center of Chemistry, University of Minho, Campus de Gualtar 4710-057 Braga, Portugal

${ }^{e}$ Laboratory of Microbiology, Department of Biological Sciences, Faculty of Pharmacy, University of Porto, Portugal

* Authors to whom correspondence should be addressed (Isabel C.F.R. Ferreira; e-mail: iferreira@ipb.pt; telephone +351-273-303219; fax +351-273-325405 and M. Helena Vasconcelos; e-mail: hvasconcelos@ipatimup.pt; telephone +351-22-5570700; fax $+351-22-5570799)$. 


\section{Abstract}

Several edible mushrooms extracts are known to have tumour cell growth inhibitory potential. The objective of this work was to study this potential in extracts of Suillus luteus collected from the Northeast of Portugal. Various extracts were prepared and their effect on tumour cell growth was studied with the SRB assay in four human tumour cell lines: MCF-7 (breast), NCI-H460 (non-small cell lung cancer), AGS (gastric) and HCT-15 (colon). The methanolic extract of S. luteus was the most potent extract. This extract was slightly more potent in the HCT-15 cells (with mutant p53, $\mathrm{GI}_{50}=17.8 \pm 1.6 \mu \mathrm{g} / \mathrm{mL}$ ) than in the other cell lines tested, which suggested that its effect was not p53-dependent. Indeed, in HCT-15 cells, an increase in the levels of p53 was detected but no alterations in some of the proteins transactivated by p53 (e.g. p21 or Bax) were found. The extract caused an increase in the cellular levels of p-H2A.X, which is suggestive of DNA damage. Growth inhibition in these cells was mostly due to inhibition of cell proliferation and an increase in the $\%$ of cell in the G1 phase of the cell cycle. An increase in cell death was also found, even though to very low levels. In addition, this extract was not cytotoxic to primary cultures of porcine hepatocytes $\left(\mathrm{GI}_{50}>400 \mu \mathrm{g} / \mathrm{mL}\right)$. Together, these results indicate that the $S$. luteus methanolic extract may be an interesting source of compounds that inhibit the proliferation of tumour cells but further studies should be carried out in order to understand its potential.

Keywords: Suillus luteus; methanolic extract; tumour cell growth; tumour cell proliferation. 


\section{Introduction}

The majority of new drugs have been generated from either natural products (secondary metabolites) or analogs inspired by them. Many drugs such as antibiotics (penicillin, tetracycline and erythromycin), antiparasitics (avermectin), antimalarials (quinine, artemisinin), lipid control agents (lovastatin and analogs), immunosuppressants for organ transplants (cyclosporin, rapamycins) or anticancer drugs (taxol, doxorubicin) have been found or produced in this way (Li \& Vederas, 2009).

Mushrooms (macrofungi) contain a vast diversity of biomolecules with nutritional (Kalač, 2009) and/or medicinal properties (Poucheret, Fons, \& Rapior, 2006). They have been recognized as functional foods and as a source of compounds for the development of nutraceuticals or medicines, including compounds with antitumour properties (Zaidman, Yassin, Mahajna, \& Wasser, 2005; Moradali, Mostafavi, Ghods, \& Hedjaroude, 2007).

The most studied compounds are high-molecular-weight ones, such as the $\beta$-glucans "Lentinan" from the fruiting bodies of Lentinus edodes, "Schizophyllan" from the culture fluid of Schizophyllum commune, or the polysaccharopeptides PSP and "Krestin" (PSK) from the cultured mycelium of Coriolus versicolor (Ferreira, Vaz, Vasconcelos \& Martins, 2010; Luk et al., 2011). Despite their commercialization, limited clinical studies in cancer patients have been conducted. In addition to the mentioned well-known medicinal mushrooms, previous work from our research group showed that other wild unexplored species from Portugal are notable for their promising antitumour potential, such as Clitocybe alexandri and Suillus collinitus. Indeed, their phenolic extracts (including low molecular weight compounds) showed effects on cell 
cycle and induced apoptosis in human lung and breast cancer cell lines, respectively (Vaz et al., 2012a; Vaz et al., 2012b).

Following our research in wild edible species from Northeast Portugal, the present work describes the cytotoxic activity of methanolic, ethanolic and boiled water extracts of $S$. luteus in various human tumor cell lines: lung, breast, colon and gastric cancer. The extract with the highest cell growth inhibitory activity (methanolic extract) was chosen to be further investigated regarding its possible mechanism of action in the most susceptible cell line studied (colon cancer), by evaluation of its effect on the cell cycle profile, cellular proliferation and apoptosis. The chemical characterization of S. luteus was previously reported by our research group. This mushroom presented protochatechuic acid $(0.47 \mathrm{mg} / 100 \mathrm{~g}$ dry weight), cinnamic acid $(0.41 \mathrm{mg} / 100), \alpha-$ tocopherol (19.14 $\mu \mathrm{g} / 100 \mathrm{~g}), \beta$-tocopherol (15.34 $\mu \mathrm{g} / 100 \mathrm{~g}), \gamma$-tocopherol (366.77 $\mu \mathrm{g} / 100 \mathrm{~g}), \delta$-tocopherol $(78.51 \mu \mathrm{g} / 100 \mathrm{~g})$, mannitol (1.29 g/100 g), trehalose (1.35 $\mathrm{g} / 100 \mathrm{~g})$, polyunsaturated fatty acids $(52.75 \%$, with linoleic acid- $52.31 \%$ - as the main fatty acid), monounsaturated fatty acids (32.93\%, with oleic acid- $31.24 \%$ - as the main fatty acid), and saturated fatty acids (14.32\%, with palmitic acid- $10.57 \%$ as the main fatty acid) (Reis et al., 2011).

\section{Materials and Methods}

\subsection{Sample collection and preparation of the extracts}

Samples of Suillus luteus (L.: Fries) Gray (edible mushroom) were collected in Bragança (Northeast Portugal), in autumn 2009. Taxonomic identification of sporocarps was made according to Coutecuisse \& Duhem (2005) and representative voucher specimens were deposited at the herbarium of Escola Superior Agrária of Instituto 
Politécnico de Bragança. The samples were lyophilised (Ly-8-FM-ULE, Snijders, Holland) and reduced to a fine powder (20 mesh).

Enriched phenolic (methanolic and ethanolic) and polysaccharidic (boiled water) extracts were prepared from the lyophilised powder following the procedure previously described by us (Vaz et al., 2010). Briefly, to obtain the methanolic extract, the lyophilized sample $(\sim 2 \mathrm{~g})$ was extracted twice with methanol $(50 \mathrm{~mL})$ mixture at $-20{ }^{\circ} \mathrm{C}$ for $6 \mathrm{~h}$. The extract was sonicated for $15 \mathrm{~min}$, centrifuged at $4000 \times g$ for $10 \mathrm{~min}$, filtered through Whatman $n^{\circ} 4$ paper and concentrated under reduced pressure (rotary evaporator Büchi R-210). To obtain the polysaccharidic (boiling water) extract, the lyophilized sample $(\sim 1.5 \mathrm{~g})$ was extracted three times with water at boiling temperature $(50 \mathrm{~mL})$ for $2 \mathrm{~h}$ and subsequently filtered through Whatman No. 4 paper. The combined extracts were lyophilized, and then $95 \%$ ethanol $(10 \mathrm{~mL})$ was added and polysaccharides were precipitated overnight at $4{ }^{\circ} \mathrm{C}$. The precipitated polysaccharides were collected after centrifugation (Centorion K24OR- 2003 refrigerated centrifuge) at $3100 \times g$ for 40 min followed by filtration, and then were lyophilized, resulting in a crude polysaccharidic sample. The ethanolic supernatant was concentrated under reduced pressure, giving the ethanolic extract.

For the subsequent assays, the extracts were re-dissolved in DMSO and the solutions were stored at $-20^{\circ} \mathrm{C}$ until further use.

\subsection{Cell Culture}

2.2.1. Human tumour cell lines. The cell lines used were: NCI-H460 (lung cancer), AGS (gastric cancer), MCF-7 (breast cancer) and HCT-15 (colon cancer). Cells were plated in RPMI 1640 medium supplemented with 5\% heat-inactivated FBS (Lonza). All cultures were incubated at $37{ }^{\circ} \mathrm{C}$ in a humidified atmosphere containing $5 \% \mathrm{CO}_{2}$. 
2.2.2. Primary cells of porcine liver. A cell culture was prepared from a freshly harvested porcine liver obtained from a local slaughter house, and it was designed as PLP2. Briefly, the liver tissues were rinsed in Hank's balanced salt solution containing $100 \mathrm{U} / \mathrm{mL}$ penicillin, $100 \mu \mathrm{g} / \mathrm{mL}$ streptomycin and divided into $1 \times 1 \mathrm{~mm}^{3}$ explants. Some of these explants were placed in $25 \mathrm{~cm}^{2}$ tissue flasks in DMEM medium supplemented with $10 \%$ fetal bovine serum, $2 \mathrm{mM}$ nonessential amino acids and 100 $\mathrm{U} / \mathrm{mL}$ penicillin, $100 \mathrm{mg} / \mathrm{mL}$ streptomycin and incubated at $37{ }^{\circ} \mathrm{C}$ with a humidified atmosphere containing $5 \% \mathrm{CO}_{2}$. The medium was changed every two days. Cultivation of the cells was continued with direct monitoring every two to three days using a phase contrast microscope. The cells were cultivated in DMEM medium with 10\% FBS, 100 $\mathrm{U} / \mathrm{mL}$ penicillin and $100 \mu \mathrm{g} / \mathrm{mL}$ streptomycin (Abreu et al., 2011).

\subsection{Analysis of cell growth}

The effects of the extracts on the growth of human tumour cell lines was evaluated, according to the procedure adopted in the NCI's in vitro anticancer drug screening (Skehan et al., 1990). Each cell line was plated at an appropriate density $\left(5.0 \times 10^{3}\right.$ cells/well for NCI-H460 and MCF-7, $1.0 \times 10^{4}$ cells/well for HCT-15 and $7.5 \times 10^{3}$ cells/well for AGS, and $1.0 \times 10^{4}$ cells/well for PLP2) in 96-well plates and allowed to attach for $24 \mathrm{~h}$. Cells were then treated for $48 \mathrm{~h}$ with various extract concentrations. The DMSO concentrations used presented no growth inhibitory effect in these cell lines.

Following this incubation period, the adherent cells were fixed with $10 \%$ trichloroacetic acid (final concentration), stained with SRB and excess dye washed with $1 \%$ acetic acid. The bound SRB was solubilised with $10 \mathrm{mM}$ Tris and the absorbance was measured at $510 \mathrm{~nm}$ in a microplate reader (Multi-mode microplate synergy ${ }^{\mathrm{TM}} \mathrm{MX}$, 
Biotek) and analysed with the Gen5 $5^{\mathrm{TM}}$ software (Biotek). The concentration that inhibited growth in 50\% (GI $\left.\mathrm{G}_{50}\right)$ was calculated according to Monks et al. (1991) and as previously described by the authors (Vaz et al., 2010).

\subsection{Cell cycle analysis}

For the analysis of cell cycle phase distribution, HCT-15 cells were plated at $2 \times 10^{5}$ cells/well in 6-well plates and incubated for $24 \mathrm{~h}$. Cells were then incubated with complete medium (blank), with $S$. luteus methanolic extract at the $\mathrm{GI}_{50}$ and $2 \times \mathrm{GI}_{50}$ concentrations or with DMSO (control). Cells were harvested following a 24 and $48 \mathrm{~h}$ of incubation period with the extract, further fixed in $70 \%$ ethanol and kept at $4^{\circ} \mathrm{C}$ until analysis. Prior to analysis, cells were incubated with Propidium Iodide ( $5 \mu \mathrm{g} / \mathrm{mL})$ and RNase A in PBS (100 $\mu \mathrm{g} / \mathrm{ml})$ for $30 \mathrm{~min}$ on ice (Vaz et al., 2012a).

Cellular DNA content was analyzed at the Advanced Flow Cytometry Unit (IBMC/INEB) using a FACS Calibur (BD) flow cytometer. Cell cycle profile was subsequently analysed using the FlowJo 7.2 software (Queiroz et al., 2010).

\subsection{Programmed cell death (TUNEL) and proliferation (BrdU) asssay}

For the TUNEL and BrdU assay, cells were plated, respectively at $7.5 \times 10^{4}$ per well in 12-well plates, and $2 \times 10^{5}$ per well in 6 -well plates, and incubated for $24 \mathrm{~h}$. Cells were then further incubated with complete medium (blank), with $S$. luteus methanolic extract at the $\mathrm{GI}_{50}$ and $2 \times \mathrm{GI}_{50}$ concentrations or with DMSO (control).

For the TUNEL assay, cells were harvested following a 24 and $48 \mathrm{~h}$ incubation with the extract, further fixed in $4 \%$ PFA and kept in PBS at $4{ }^{\circ} \mathrm{C}$ until analysis. Cytospins were prepared and cells were permeabilized in ice cold $0.1 \%$ Triton X-100 in $0.1 \%$ sodium citrate for 2 min. Programmed cell death was assessed using the "in situ cell death 
detection kit" (Roche, Basel Switzerland). Briefly, cells were incubated with the TUNEL reaction mix (enzyme diluted 1:20) for $1 \mathrm{~h}$, as previously described (Palmeira et al., 2010).

For the BrdU assay, $23 \mathrm{~h}$ following incubation with the extract, cells were given a pulse of $\operatorname{BrdU}(10 \mu \mathrm{M}$, Sigma) for $1 \mathrm{~h}$ and were then washed and fixed in $4 \%$ paraformaldehyde in phosphate buffer saline. Cytospins were prepared and incubated in $2 \mathrm{M} \mathrm{HCl}$ for $20 \mathrm{~min}$. They were then incubated with mouse anti-BrdU (1:10, Dako) and further incubated with fluorescein-labeled rabbit anti-mouse antibody (1:100, Dako), as previously described (Palmeira et al., 2010).

For the analysis of slides from both the TUNEL and the BrdU assay, slides were mounted in Vectashield Mounting Media with DAPI (Vector Laboratories). Cells were observed in a DM2000 microscope (LEICA) and a semi-quantitative evaluation of the levels of programmed cell death or proliferation was performed by counting a minimum of 500 cells per slide.

\subsection{Protein expression analysis}

Cells were plated at $2 \times 10^{5}$ per well in 6-well plates and incubated for $24 \mathrm{~h}$. They were then treated with complete medium (blank), the solvent of the extract (DMSO) or with the $\mathrm{GI}_{50}$ or $2 \times \mathrm{GI}_{50}$ concentration of the methanolic extract of $S$. luteus and processed 48 h later. Briefly, cells were lysed in Winman's buffer $(1 \% \mathrm{NP}-40,0.1 \mathrm{M}$ Tris- $\mathrm{HCl} \mathrm{pH}$ 8.0, $0.15 \mathrm{M} \mathrm{NaCl}$ and $5 \mathrm{mM}$ EDTA) with EDTA-free protease inhibitor cocktail (Boehringer Mannheim). Proteins were quantified with the DC Protein Assay kit (BioRad), separated in 12\% (resolving) and 5\% (Stacking) tris-glycine sodium dodecyl sulfate (SDS)-polyacrylamide gels and transferred to a nitro-cellulose membrane (GE Healthcare). Membranes were incubated with the following primary antibodies for $\mathrm{p} 53$ 
(1:200, Calbiochem), p73 (1:500), Bax (1:500, Santa Cruz Biotechnology), p21 (1:250, Thermo scientific), p-H2A.X (1:200), Actin (1:2000, Santa Cruz Biotechnology), and then incubated with the respective secondary antibodies- horseradish peroxidase (HRP) conjugated (1:2000, Santa Cruz Biotechnology). The signal was detected with the Amersham ECL kit (GE Healthcare), Hyperfilm ECL (GE Healthcare) and Kodak GBX developer and fixer twin pack (Sigma), as previously described (Vasconcelos et al., 2000). The intensity of the bands obtained in each film was further analyzed using the software Quantity One - 1D Analysis (Bio-Rad), as previously described (Palmeira et al., 2010).

\subsection{Statistical analysis}

Results were expressed as mean values \pm standard deviation (SD) of at least 3 independent experiments, performed in duplicate. Statistical significance was tested with a two tailed paired Student's t-Test using the DMSO as a negative control. * Indicates $p<0.05$.

\section{Results and Discussion}

3.1. The methanolic extract of S. luteus presents cell growth inhibitory activity in various human tumour cell lines but not in primary porcine liver cells

The enriched phenolic (methanolic and ethanolic) and polissacharidic (boiled water) extracts of $S$. luteus were screened for tumour cell growth inhibitory potential in four human tumour cells lines (NCI-H460, MCF-7, HCT-15 and AGS). The determined values of $\mathrm{GI}_{50}$ (concentrations that caused $50 \%$ cell growth inhibition) are expressed in Table 1. The methanolic extract was the most potent extract in all the cell lines tested, 
since the other extracts did not reach the $\mathrm{GI}_{50}$ at the concentrations tested (up to 400 $\mu \mathrm{g} / \mathrm{ml}$ ). Léon et al. (2008) had previously shown that suillumide, a ceramide isolated from the ethanolic extract of $S$. luteus, presented cytotoxic activity against a human melanoma cell line (with $\mathrm{IC}_{50}$ values of approximately $10 \mu \mathrm{M}$ following a $72 \mathrm{~h}$ treatment). Nonetheless, in our study the ethanolic extract did not present significant cytotoxic activity (in the studied cell lines and up to the concentrations tested).

S. luteus methanolic extract had previously been reported to present cytotoxic activity against a murine cancer cell line (Tomasi, 2004). Nevertheless, to our knowledge, this is the first study that shows a cytotoxic activity in human tumour cell lines.

The cell line which was most sensitive to the effect of this extract was the HCT-15 cell line $\left(\mathrm{GI}_{50}=17.75 \pm 1.6 \mu \mathrm{g} / \mathrm{mL}\right)$. Therefore, this cell line was selected to further study the effect of this extract. Interestingly, this extract was not cytotoxic to primary cultures of porcine hepatocytes $\left(\mathrm{GI}_{50}>400 \mu \mathrm{g} / \mathrm{mL}\right.$, Table 1).

3.2.The methanolic extract of $S$. luteus reduces the proliferation of HCT-15 cells and causes a cell cycle arrest in G1

The HCT-15 cells were treated with the $\mathrm{GI}_{50}(17.75 \mu \mathrm{g} / \mathrm{mL})$ or twice the $\mathrm{GI}_{50}$ concentration $(35.5 \mu \mathrm{g} / \mathrm{mL})$ of the methanolic extract of $S$. luteus. The effect on cellular proliferation was analysed upon $24 \mathrm{~h}$ incubation and on cell cycle profile upon $24 \mathrm{~h}$ and $48 \mathrm{~h}$ incubation. Results from the cell cycle profile analysis show that this extract caused an increase in the $\%$ of cells in the G1 phase of the cell cycle, which was more evident (and statistically significant) with twice the $\mathrm{GI}_{50}$ concentration, mostly $24 \mathrm{~h}$ following treatment (Figure 1A) . In addition, treatment with the extract caused a statistically significant decrease in the \% cells in the $\mathrm{S}$ and $\mathrm{G} 2 / \mathrm{M}$ phases of the cell cycle, when cells were treated with twice the $\mathrm{GI}_{50}$ concentration for $24 \mathrm{~h}$ (Figure 1A). 
A decrease in the $\%$ cells in the $\mathrm{S}$ phase was also obtained when cells were treated with the $\mathrm{GI}_{50}$ for $24 \mathrm{~h}$ and a statistically significant decrease in $\mathrm{G} 2 / \mathrm{M}$ when cells were treated with twice the $\mathrm{GI}_{50}$ concentration for $48 \mathrm{~h}$ (Figure 1B).

In agreement with this cell cycle arrest in G1, treatment of HCT-15 cells with the extract caused a concentration dependent decrease in cellular proliferation, which was very strong and statistically significant when cells were treated with twice the $\mathrm{GI}_{50}$ concentration (Figure 2).

\subsection{The methanolic extract of S. luteus does not interfere with programmed cell death of} HCT-15 cells

The effect of the extract on programmed cell death of HCT-15 cells was investigated with the TUNEL assay. Treatment during $24 \mathrm{~h}$ with the GI50 concentration or during $24 \mathrm{~h}$ or $48 \mathrm{~h}$ with twice the $\mathrm{GI}_{50}$ concentration of the extract increased cell death, even though to very low levels (Table 2).

\subsection{The activity of the methanolic extract of S. luteus does not depend on $p 53$}

The HCT-15 cell line has heterozygous mutations in the p53 tumour suppressor gene (O'Connor et al., 1997). Even though it would be possible that the remaining wild-type allele could remain functional, this cell line has been documented, by a reporter assay monitoring p53-dependent transactivation in cells, to lack functional p53 (Falck et al., 2001). Therefore, the fact that the methanolic extract of $S$. luteus was more potent in this cell line than in the other studied cell lines indicated that the effect of this extract was, at least in this cell line, not p53 dependent. Indeed, even though HCT-15 cells treated with the extract presented an increase in p53 expression (Figure 3A), there was no increase in some of the proteins transactivated by wild-type $\mathrm{p} 53$, such $\mathrm{p} 21$ or Bax 
(Figure 3B and 3C). In fact, the levels of Bax, a proapoptotic protein that has the ability to form oligomers on the outer mitochondrial membrane causing membrane permeabilization and apoptosis (Lamb \& Hardwick, 2013), were surprisingly decreased. The reason for this decrease in the levels of Bax is not understood, since equal levels were expected as mutant p53 in known to be unable to activate Bax transcription (Campomenosi et al., 2001). Nevertheless, this decrease in Bax might explain the low levels of cell death that were detected upon treatment of cells with the mushroom extract.

The p53 family has several isoforms and many of the functions of the p53 tumour suppressor protein may be shared by other members of this family, such as the p 73 protein (Müller et al., 2006). Therefore, the effect of the extract on the levels on p73 protein was studied. No difference in $\mathrm{p} 73$ protein levels was found, indicating that $\mathrm{p} 73$ is not involved in the effect of this extract (Figure 3D).

Finally, the levels of p-H2A.X were determined and found to be increased upon treatment of the cells with twice the $\mathrm{GI}_{50}$ concentration of the extract (Figure 3E). This increase is suggestive of DNA damage and could justify the increase in the p53 levels previously found.

In conclusion, it may be interesting to further study this extract, considering that many tumours present mutant p53 tumour suppressor gene and that this extract is capable of decreasing cellular proliferation in the absence of functional p53, an event most likely triggered by an increase in DNA damage. Nonetheless, further studies regarding the cellular effects resulting from the increase in mutant p53 levels need to be carried out, since some mutant p53 have gain of function and may lead to a decrease in apoptosis, decrease in growth arrest, decrease in senescence and increase in chemoresistance 
(Strano et al., 2007). Therefore, an increase in mutant p53 may have deleterious cellular effects.

The mechanisms or pathways leading to the observed decrease in cellular proliferation may be complex and need to be further studied. We found no evidence of p73 being involved in this pathway, at least in the HCT-15 cell line (which presents mutant p53), but other p53 family proteins (DeYoung and Ellisen, 2007) may be involved. In addition, many studies have demonstrated that Bcl-2 and Bax also have an effect on cellular proliferation. For example, bax has been shown to reverse the proliferation retarding activities of Bcl-2 (Borner, 1996 and O'Reilly, 1996). Therefore, the decrease in Bax levels that were found following treatment with the mushroom extract may be related to the observed decrease in cellular proliferation. Further studies need to be carried out in order to evaluate this hypothesis. It would be interesting to identify the compound or compounds responsible for the biological activity here described. Nevertheless, in a previous work we identified and quantified protocatechuic and cinnamic acids in S. luteus methanolic extract, and these compounds could possibly be related not only to the antioxidant activity reported in that study (Reis et al., 2011), but also to the capacity to decrease cellular proliferation in the herein tested colon cancer cell line.

\section{Acknowledgements}

The authors are grateful to Fundação para a Ciência e a Tecnologia (FCT, Portugal) and COMPETE/QREN/EU for financial support to this work (research project PTDC/AGRALI/110062/2009) and to CIMO (strategic project PEst-OE/AGR/UI0690/2011). They also thank to University of Porto and Santander Totta for financial support. J.A Vaz thanks to FCT, POPH-QREN and FSE for her grant (BD/43653/2008). G.M. Almeida is 
supported by FCT and the European Social Fund. IPATIMUP is an Associate Laboratory of the Portuguese Ministry of Science, Technology and Higher Education and is partially supported by FCT.

\section{References}

Abreu, R.M.V., Ferreira, I.C.F.R., Calhelha, R.C., Lima, R.T., Vasconcelos, M.H., Adega, F., Chaves, R., \& Queiroz, M.J.R.P. (2011). Anti-hepatocellular carcinoma activity using human HepG2 cells and hepatotoxicity of 6-substituted methyl 3aminothieno[3,2-b]pyridine-2-carboxylate derivatives: In vitro evaluation, cell cycle analysis and QSAR studies. European Journal of Medicinal Chemistry, 46, $5800-5806$.

Borner, C. (1996). Diminished cell proliferation associated with the death-protective activity of Bcl-2. Journal of Biological Chemistry, 22, 12695-8.

Campomenosi, P., Paola, Monti, P., Aprile, A., Abbondandolo, A., Frebourg, T., Gold, B., Crook, T., Inga, A., Resnick, M.A., Iggo, R., \& Fronza, G. (2001). Oncogene, $20,3573-3579$.

Courtecuisse, R., \& Duhem, B. (2005). Guía de los hongos de la Peninsula Ibérica, Europa y Norte de África. Barcelona: Ediciones Omega.

DeYoung, M.P., \& Ellisen, L.W. (2007). p63 and p73 in human cancer: defining the network. Oncogene, 26, 5169-5183.

Falck, J., Lukas, C., Protopopova, M., Lukas, J., Selivanova, G., \& Bartek. J. (2001). Functional impact of concomitant versus alternative defects in the Chk2-p53 tumour suppressor pathway.Oncogene, 20, 5503-5510. 
Ferreira, I.C.F.R., Vaz, J.A., Vasconcelos, M.A., \& Martins, A. (2010). Compounds from wild mushrooms with antitumour potential. Anti-Cancer Agents in Medicinal Chemistry, 10, 424-436.

Kalač, P. (2009). Chemical composition and nutritional value of European species of wild growing mushrooms: A review. Food Chemistry, 113, 9-16.

Lamb, H.M., \& Hardwick, J.M. (2013). Unlatched BAX pairs for death. Cell, 152, 383384.

León, F., Brouard, I., Torres, F., Quintana, J., Rivera, A., Estévez, F., \& Bermejo, J. (2008). A new ceramide from Suillus luteus and its cytotoxic activity against human melanoma cells. Chemical Biodiversity, 5, 120-125.

Li, J. W-H, \& Vederas, J.C. (2009). Drug discovery and natural products: end of an era or an endless frontier. Science, 325, 161-165.

Luk, S.-U., Lee, T.K.-W., Liu, J., Lee, D.T.-W., Chiu, Y.-T., Ma, S., Ng, I.O.-L., Wong, Y.-C., Chan, F.L., \& Ling, M.T. (2011). Chemopreventive effect of PSP through targeting of prostate cancer stem cell-like population. PLoS ONE, 6, e19804.

Monks, A., Scudiero, D., Skehan, P., Shoemaker, R., Paull, K., Vistica, D., Hose, C., Langley, J., Cronise, P., Vaigro-Wolff, A., Gray-Goodrich, M., Campbell, H., Mayo, J., \& Boyd, M. (1991). Feasibility of a high-flux anticancer drug screen using a diverse panel of cultured human tumor cell lines. Journal of the National Cancer Institute, 83, 757-766.

Moradali, M.-F., Mostafavi, H., Ghods, S., \& Hedjaroude, G.-A. (2007). Immunomodulating and anticancer agents in the realm of macromycetes fungi (macrofungi). International Immunopharmacology, 7, 701-724. 
Müller, M., Schleithoff, E.S., Stremmel, W., Melino, G., Krammerd, P.H. \& Schilling, T. (2006). One, two, three- p53, p63, p73 and chemosensitivity. Drug Resistance Updates, 9, 288-306.

O'Connor, P.M., Jackman, J., Bae, I., Myers, T.G., Fan, S., Mutoh, M., Scudiero, D.A., Monks, A., Sausville, E.A., Weinstein, J.N., Friend, S., Fornace, A.J. Jr, \& Kohn, K.W. (1997). Characterization of the p53 tumor suppressor pathway in cell lines of the National Cancer Institute anticancer drug screen and correlations with the growth-inhibitory potency of 123 anticancer agents. Cancer Research, 57, 4285-4300.

O’Reilly, L.A., Huang, D.C.S., \& Strasser, A. (1996). The cell death inhibitor Bcl-2 and its homologues influence control of cell cycle entry. EMBO Journal, 15, 69796990.

Palmeira, A., Paiva, A., Sousa, E., Seca, H., Almeida, G.M., Lima, R.T., Fernandes, M.X., Pinto, M., \& Vasconcelos, M.H. (2010). Insights into the in vitro antitumor mechanism of action of a new pyranoxanthone. Chemical Biology and Drug Design, 76, 43-58.

Poucheret, P., Fons, F., \& Rapior, S. (2006). Biological and pharmacological activity of higher fungi: 20-Year retrospective analysis. Cryptogamie Mycologie, 27, 311333.

Queiroz, M.J., Calhelha, R.C., Vale-Silva, L.A., Pinto, E., Lima, R.T., \& Vasconcelos, M.H. (2010). Efficient synthesis of 6-(hetero)arylthieno[3,2-b]pyridines by Suzuki-Miyaura coupling: Evaluation of growth inhibition on human tumor cell lines, SARs and effects on the cell cycle. European Journal of Medicinal Chemistry, 45, 5628-5634. 
Reis, F.S., Heleno, S.A., Barros, L., Sousa, M.J., Martins, A., Santos-Buelga, C., \& Ferreira, I.C.F.R. (2011). Toward the antioxidant and chemical characterization of mycorrhizal mushrooms from Northeast Portugal. Journal of Food Science, $76,824-830$.

Skehan, P., Storeng, R., Scudiero, D., Monks, A., MacMahon, J., Vistica, D., Warren, J.T., Bokesch, H., Kenney, S., \& Boyd, M.R. (1990). New colorimetric cytotoxicity assay for anticancer-drug screening. Journal of the National Cancer Institute, 82, 1107-1112.

Strano, S.S., Dell’Orso, S., Di Agostino, S., Fontemaggi, G., Sacchi, A. \& Blandino, G. (2007). Mutant p53: an oncogenic transcription factor. Oncogene, 26, 22122219.

Tomasi, S., Lohézic-Le Dévéhat, F., Sauleau, P., Bézivin, C., \& Boustie, J. (2004). Cytotoxic activity of methanol extracts from Basidiomycete mushrooms on murine cancer cell lines. Pharmazie, 59, 290-293.

Vasconcelos, M.H., Beleza, S.S., Quirk, C., Maia, L.F., Sambade, C., \& Guimarães, J.E. (2000). Limited synergistic effect of antisense oligonucleotides against bcr-abl and transferrin receptor mRNA in leukemic cells in culture. Cancer Letters, $152,135-143$.

Vaz, J.A., Heleno, S.A., Martins, A., Almeida, G.M., Vasconcelos, M.H., \& Ferreira, I.C.F.R. (2010). Wild mushrooms Clitocybe alexandri and Lepista inversa: In vitro antioxidant activity and growth inhibition of human tumour cell lines. Food and Chemical Toxicology, 48, 2881-2884.

Vaz, J.A., Almeida, G.M., Ferreira, I.C.F.R., Martins, A., \& Vasconcelos, M.H. (2012a). Clitocybe alexandri extract induces cell cycle arrest and apoptosis in a 
lung cancer cell line: identification of phenolic acids with cytotoxic potential. Food Chemistry, 132, 482-486.

Vaz, J.A., Ferreira, I.C.F.R., Tavares, C., Almeida, G.M., Martins, A., \& Vasconcelos, M.H. (2012b). Suillus collinitus methanolic extract increases p53 expression and causes cell cycle arrest and apoptosis in a breast cancer cell line. Food Chemistry, $135,596-602$

Zaidman, B.-Z., Yassin, M., Mahajna, J., \& Wasser, S.P. (2005). Medicinal mushroom modulators of molecular targets as cancer therapeutics. Applied Microbiology and Biotechnology, 67, 453-468. 
Table 1. Growth inhibitory activity of different extracts of $S$. luteus on human tumour cell lines and on primary cells of porcine liver.

\section{Tumour cell lines}

Primary cells

\begin{tabular}{|c|c|c|c|c|c|}
\hline & NCI-H460 & HCT-15 & MCF-7 & AGS & PLP2 \\
\hline Boiled water & $>400$ & $>275^{\#}$ & $>400$ & $>400$ & $>400$ \\
\hline Methanolic & $30.33 \pm 1.1$ & $17.75 \pm 1.6$ & $32.25 \pm 5.7$ & $30.30 \pm 3.1$ & $>400$ \\
\hline Ethanolic & $>400$ & $>400$ & $>400$ & $>400$ & $>400$ \\
\hline \multicolumn{6}{|c|}{ Results are expressed as $\mathrm{GI}_{50}$ (concentration of extract in $\mu \mathrm{g} / \mathrm{mL}$ that causes $50 \%$} \\
\hline
\end{tabular}


Table 2. Percentage of HCT-15 cells undergoing programmed cell death, following treatment with the methanolic extract of S. luteus.

\section{Time}

\begin{tabular}{lcc} 
& $\mathbf{2 4 h}$ & $\mathbf{4 8 h}$ \\
\hline Blank & $0.23 \pm 0.27$ & $0.39 \pm 0.15$ \\
DMSO & $0.25 \pm 0.03$ & $0.34 \pm 0.23$ \\
GI $_{\mathbf{5 0}}$ concentration & $0.76 \pm 0.15^{*}$ & $0.66 \pm 0.18$ \\
$\mathbf{2 \times \mathbf { G I } _ { \mathbf { 5 0 } } \text { concentration }}$ & $1.64 \pm 0.45^{*}$ & $1.66 \pm 0.31^{*}$ \\
\hline
\end{tabular}

Results were determined by TUNEL assay and are the mean \pm SD of at least 3 independent experiments, performed in duplicate. Statistical significance was tested by two tailed paired Student's t-Test using DMSO as a negative control. * Indicates $p<0.05$. Doxorubicin was used as a positive control. The percentage of cells undergoing programmed cell death following $24 \mathrm{~h}$ of treatment with doxorubicin was $1.95 \pm 0.61 \%$ and following $48 \mathrm{~h}$ of treatment was $17.73 \pm 3.41 \%$. 
A.

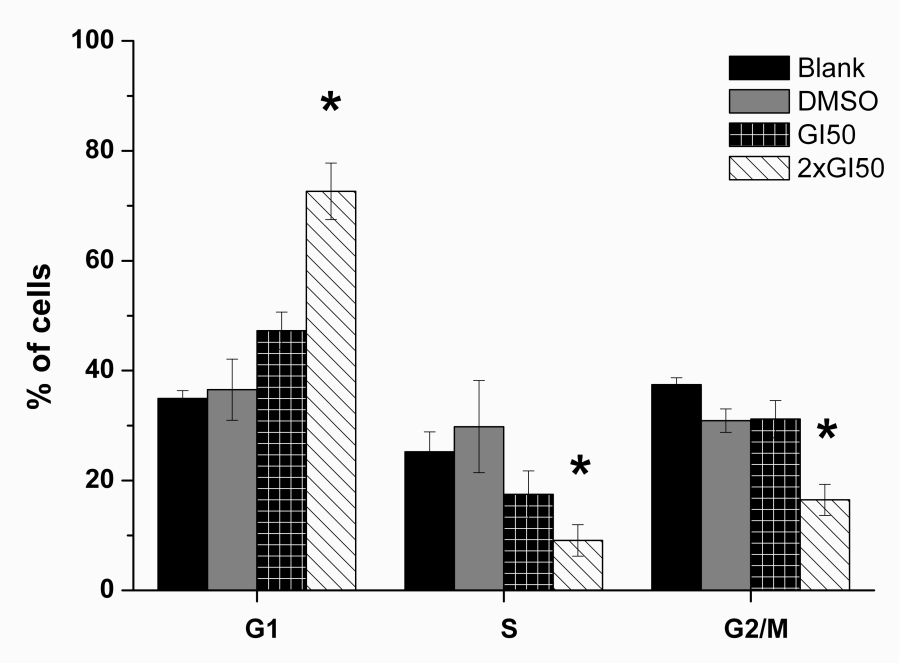

B.

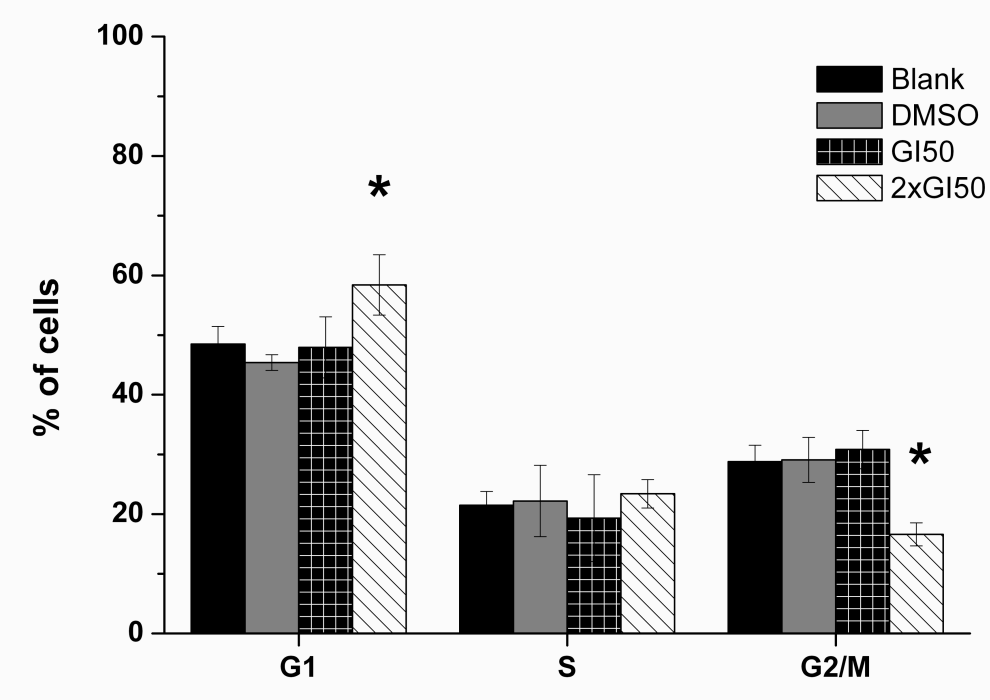

Figure 1. Cell cycle analysis of HCT-15 cells treated with the methanolic extract of $S$. luteus. Cell were treated for $24 \mathrm{~h}(\mathbf{A})$ or $48 \mathrm{~h}(\mathbf{B})$ with the $\mathrm{GI}_{50}(17.75 \mu \mathrm{g} / \mathrm{mL})$ or twice the $\mathrm{GI}_{50}$ concentrations $(35.5 \mu \mathrm{g} / \mathrm{mL})$ of the extract. Untreated cells (blank) and cells treated with DMSO (concentration corresponding to $2 \mathrm{xGI}_{50}$ concentration) were used as controls. Results are the means \pm SD of 3 independent experiments performed in 
duplicate. Statistical significance was tested by two tailed paired Student's t-Test using DMSO as a negative control. * Indicates $p<0.05$. 


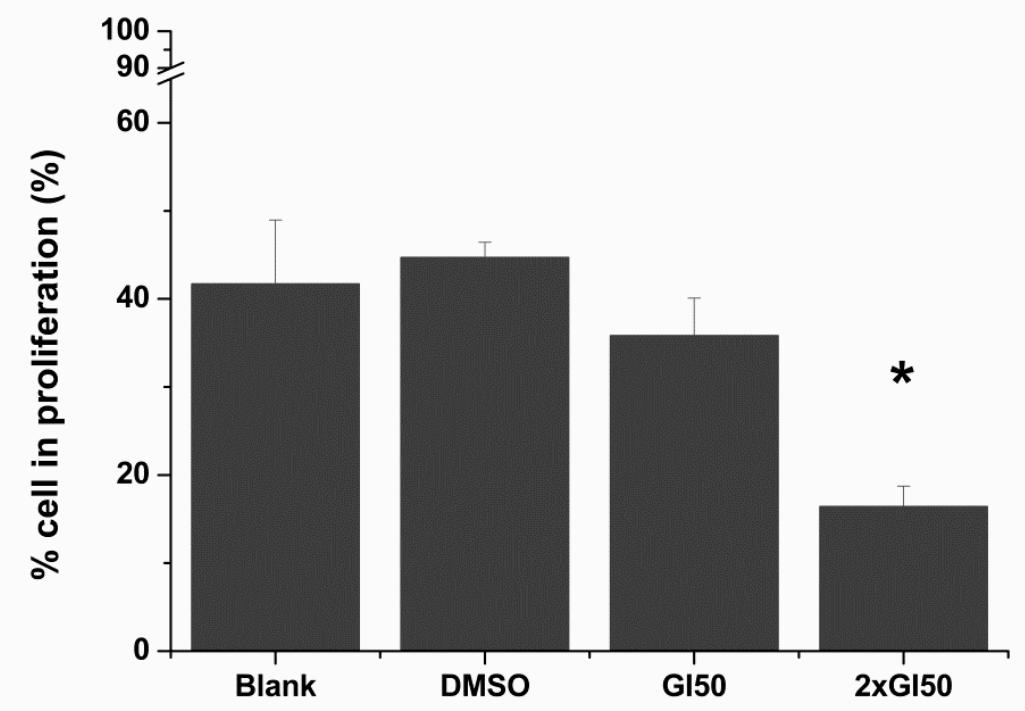

Figure 2. Cellular proliferation of HCT-15 cells treated with the methanolic extract of S. luteus. Cells were treated for $24 \mathrm{~h}$ with the $\mathrm{GI}_{50}(17.75 \mu \mathrm{g} / \mathrm{mL})$ or twice the $\mathrm{GI}_{50}(35.5$ $\mu \mathrm{g} / \mathrm{mL}$ ) concentrations of the extract. Untreated cells (Blank) and cells treated with DMSO (concentration corresponding to $2 \times \mathrm{GI}_{50}$ ) were used as controls. Results are the mean \pm SD of 3 independent experiments performed in duplicate. Statistical significance was tested by two tailed paired Student's t-Test using DMSO as a negative control. * Indicates $p<0.05$. 
A.

Blank DMso $\mathrm{Gl}_{50} \quad 2 \mathrm{Gl}_{50}$

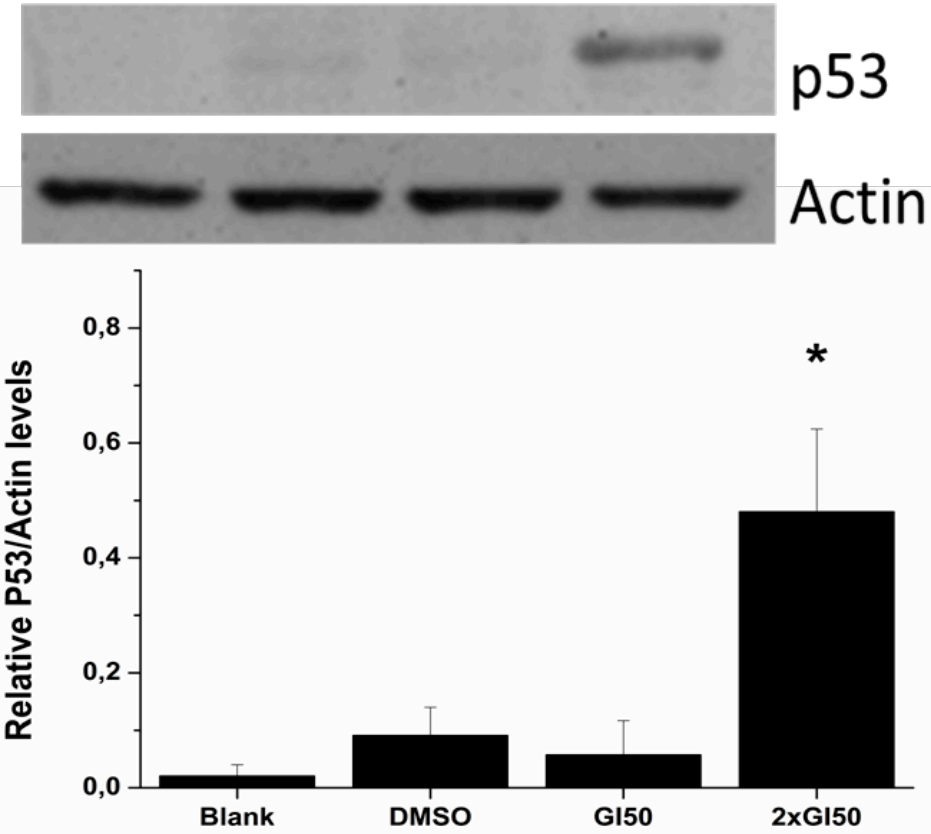

B.

Blank DMSO $\quad \mathrm{GI}_{50} \quad \mathbf{2 G I}_{50}$
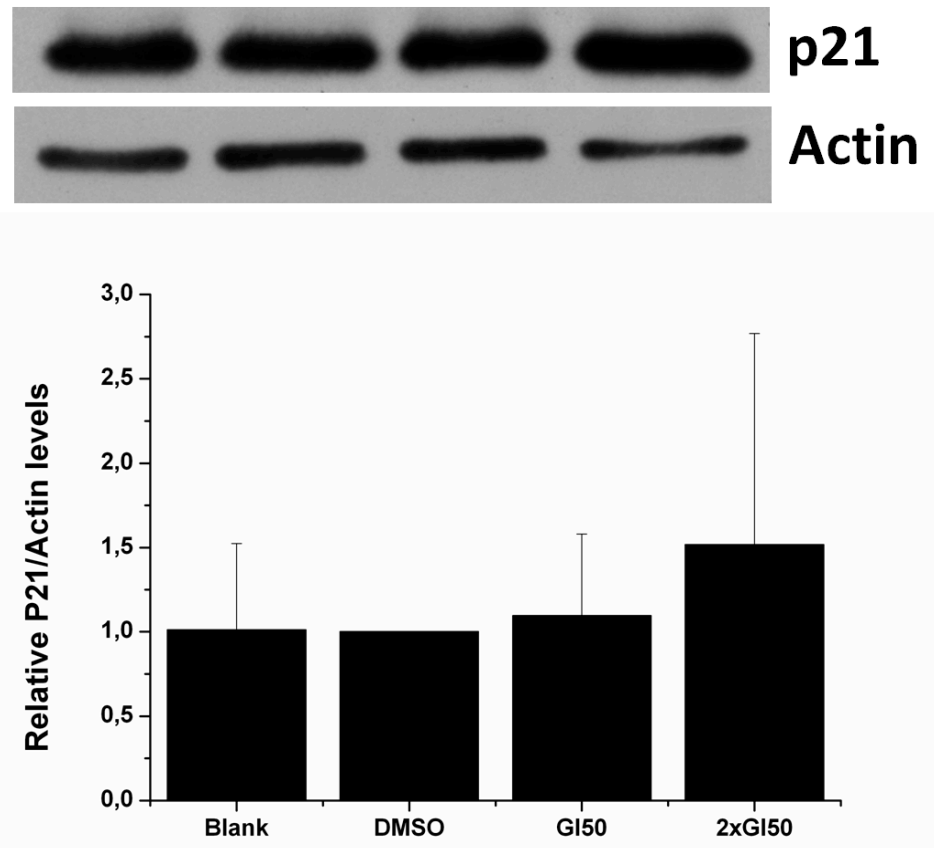
C.

Blank DMSO Gl50 2G/50
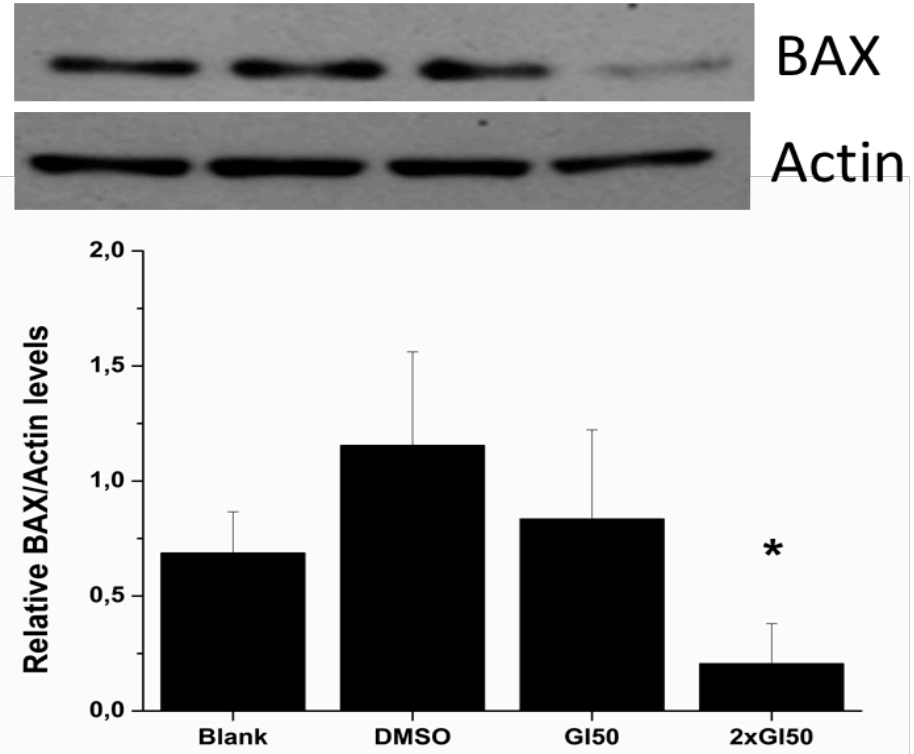

D.
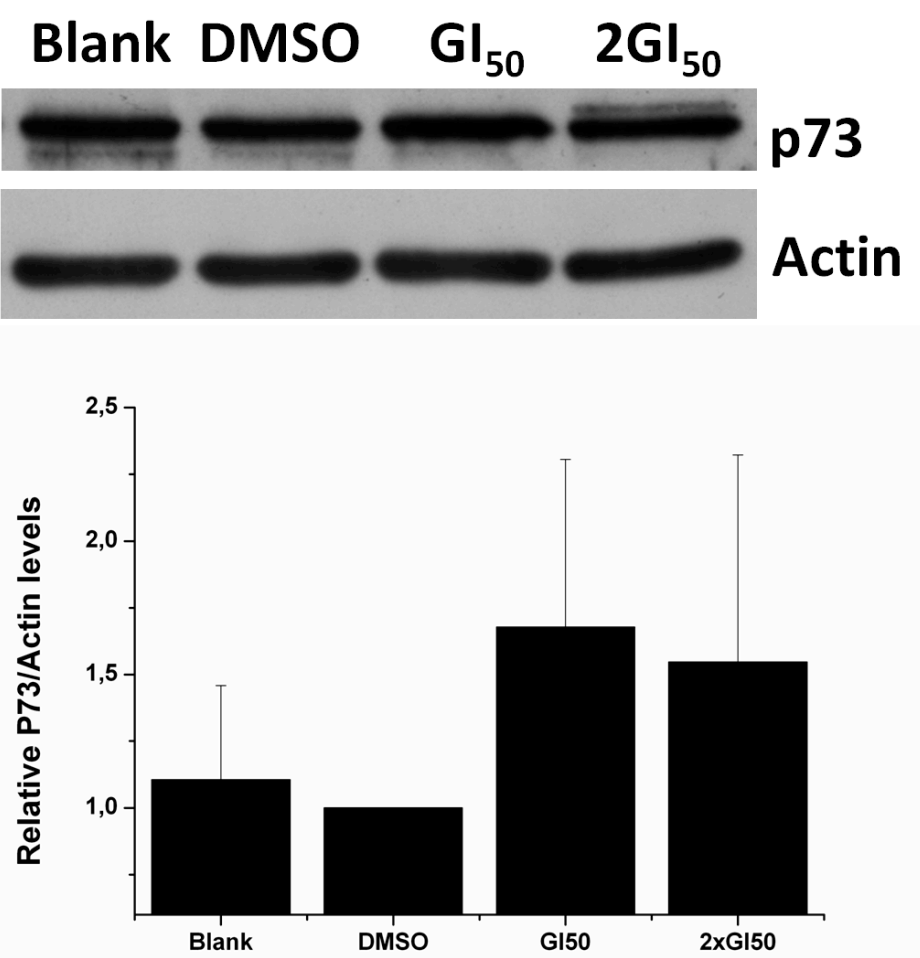
E.

Blank DMSO $\quad \mathrm{GI}_{50} \quad \mathbf{2 G I}_{50}$

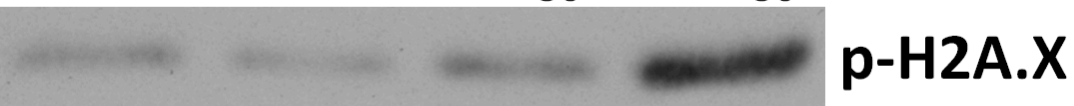

Actin

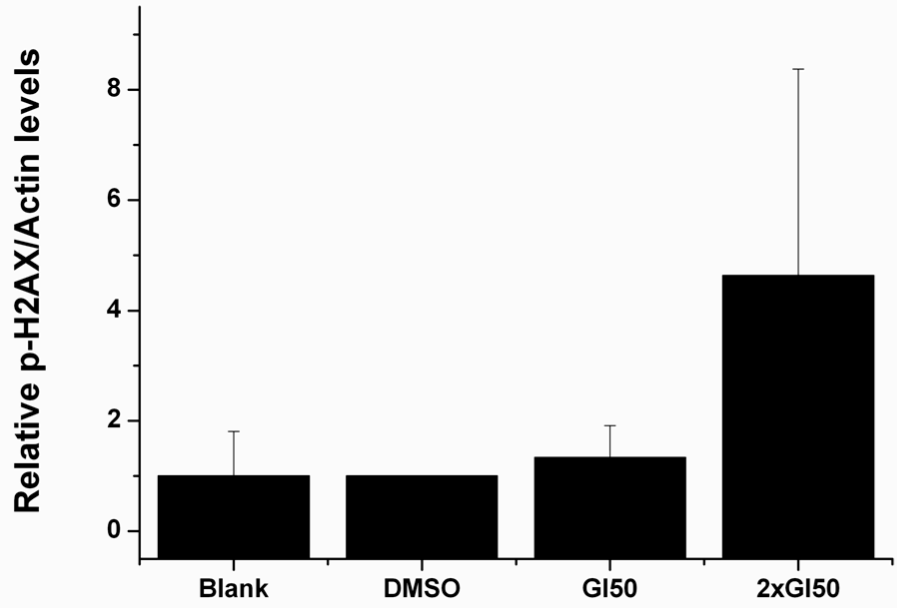

Figure 3. Protein expression of HCT-15 cells treated with the methanolic extract of $S$. luteus. The levels of p53 (A), p21 (B), Bax (C), p73 (D) and p-H2A.X (E) of cells treated for $48 \mathrm{~h}$ with the $\mathrm{GI}_{50}(17.75 \mu \mathrm{g} / \mathrm{mL})$ or twice the $\mathrm{GI}_{50}(35.5 \mu \mathrm{g} / \mathrm{mL})$ concentrations of the extract are shown. Untreated cells (Blank) and cells treated with DMSO (concentration corresponding to $2 \mathrm{xGI}_{50}$ ) were used as controls. Actin was used as the loading control. Results are the mean $\pm \mathrm{SD}$ of 3 independent experiments. Statistical significance was tested by two tailed paired Student's t-Test using DMSO as a negative control. * Indicates $p<0.05$. 